\title{
Tüketim Toplumunda Metalaştırılan Dini Yeniden Okuma Önerisi: Bireyin Dine Yabancılaşması Üzerine Bir Giriş*
}

\section{A Re-Reading Proposition the Commodificated Religion in Consumption Society: An Introduction to the Individual's Alienation to Religion}

\author{
Bekir KOÇ \\ Araştırma Görevlisi, Bingöl Üniversitesi İlahiyat Fakültesi Din Sosyolojisi \\ Anabilim Dalı. \\ Research Assistant, Bingöl University Faculty of Theology Department of \\ Sociology of Religion. \\ ORCID: org/0000-0002-5298-0448 \\ bekir_koc_55@hotmail.com
}

Geliş Tarihi: 16.04.2019, Kabul Tarihi: 13.05.2019

DOI: $10.34085 /$ buifd .554550

\section{Öz}

Tüketim, insanın yeryüzüne attığı ilk adımından günümüze kadar uzanan bir olgudur. Din de aynı tarihi serüven içerisinde kendine yer edinmektedir. Bu bağlamda tüketim ve din veya dini inanç, ibadet ve değerler, tarih boyunca farklı ilişkiler içinde olmuşlardır. Birçok sosyolog, tüketim ve din ilişkisini çeşitli yönlerden ele alarak, kendi toplumlarındaki tezahürleriyle yorumlamaya çalışmışlardır. Nitekim Marx, hem tüketim hem de din konusundaki düşünceleriyle günümüze kadar uzanan bu ilişkiyi analiz etmemize imkân vermektedir. Marx'ın sanayileşme ve kapitalist sistem bağlamında

Bu çalışma 8.7.2014 tarihinde sunulan "Türkiye'de Tüketim Toplumu ve Din: Yabancılaşma Kavramı Analizi" başlıklı yüksek lisans tezi esas alınarak hazırlanmıştır. This article is extracted from my master thesis entitled "Consumer Society and Religion in Turkey: The Analysis of The Concept Alienation" (Master Thesis, Istanbul University, Istanbul/Turkey, 2014). 
ele aldığı yabancılaşma kavramı, günümüz tüketim toplumlarında metalaştırılan dini inanç, ibadet ve değerlerin durumunun gösterilmesine sşık tutmaktadır.

Bu çalışma, dini inanç, ibadet ve değerlerin tüketim kodlarıyla sarmalanması, metalaştırılması ve topluma sunulması nedeniyle gerçekleşen bireylerin dine yabancılaşması konusunu içermektedir. Bu konu, Marx’ın yabancılaşma kavramı üzerinden günümüz Türkiye tüketim toplumunun analiz edilmesi ve dindar bireylerin sosyal durumunun gösterilmesi amacını taşımakta ve metalaştırılan dini yeniden okuyabilme önerisini sunmaya çalışmaktadır.

Anahtar Kelimeler: Tüketim Toplumu, Yabancılaşma, Din, Marx, Dine Yabancrlaşma, Türkiye.

\section{Abstract}

Consumption is a phenomenon that date from the first step taken by human being into the earth to the present day. Religion also takes its place in the same historical adventure. In this context, consumption and religion or religious beliefs, worships and values have had different relations with each other throughout history. Many sociologists have tried to interpret the relationship between consumption and religion in different aspects and interpret their situation in their own society. In fact, Marx with his thoughts on both consumption and religion allows us to analyze this relationship which date back to the present day.

The concept of alienation, which Marx deal with in the context of industrialization and capitalist system, sheds light on the state of religious beliefs, worships and values which commodificated in today's consumption societies. This study examines the alienation of individuals to religion who have been involved in religious beliefs, worships and values encapsulated with their consumption codes, commodification and presentation to society. In addition this study aims to the analysis of Marx's concept of alienation in present-day Turkey over the consumer society and to demonstrate the social status of religious individuals and is trying to offer the opportunity to be able to re-read religious commodification.

Keywords: Consumer Society, Alienation, Religion, Marx, Alienation to Religion, Turkey.

\section{GİRIŞ}

Tüketim olgusu, bireylerin gündelik yaşamlarında sürekli yaptıkları bir eylem olarak, toplumsal ilişkilerin farklı bir tezahürünü doğurmaktadır. Tüketilen metalar, ister yaşamsal ihtiyaçlar veya arzulandırılmış istekler gibi gerekliliklerle isterse işaret değeri, sosyal statü gibi tutumlar için olsun, birçok toplumsal durumu ortaya çıkarmaktadır. Dinin de tüketim olgusuna olan çeşitli etkileri (helal-haram alışveriş gibi), bu duruma yönelmenin ve onu çözümlemenin önemine işaret etmektedir. Özellikle dindar veya 
muhafazakâr tüketicilerin yaptıkları tüketim fiilinin ne tür sonuçlara götürdüğü analiz edilerek, tüketimin farklı tezahürlerine dikkat çekilebilir. Nitekim dini değer ve ritüeller için yapılan tüketim faaliyetleri, bu konuların başında gelmektedir. Ancak tüketim toplumunun tüketimsel kodlarının her şeyi tüketme arzusuna yönlendiren etkisi, dini değer, ritüel ve mekânlara da ulaşmaktadır. Bu durumda tüketimin bu etkisini analiz için kuramsal bir çerçeveye ihtiyaç duyulmaktadır. Bu çalışmada, tüketim toplumunun analiz edilmesine 1şık tutan Marx'ın yabancılaşma kavramının günümüz toplumlarında, kapitalist tüketimsel kodlarla sarmalanan ve metalaştırılarak topluma sunulan dini değer ve ritüellerin bireylerde sebep olduğu dine yabancilaşma durumunu göstererek bu ihtiyacı gidermek mümkündür.

Bu çalışmanın konusu ve bu çerçevede değinilecek örnekler, çeşitli perspektiflerden (sekülerleşme, modernizm, postmodernizm, gösterişçi tüketim kültürü, etiketleme gibi) de ele alınabilen bir zeminde olsa da, çalışmanın sinırlılıkları, bu perspektifteki tartışmalar üzerinden değil; Marx'ın yabancılaşma kavramının, yerel örnekler üzerinden yeniden okunabilmesini sağlamaya ve yeni bir yorumla değerlendirilebileceğinin imkânına dair bir giriş mahiyetinde olacaktır. Bu bakımdan çalışmamız, kuramsal bir deneme ve öneri amacı taşımaktadır.

\section{TÜKETIM KAVRAMI}

Tüketim, "Üretilen veya yapılan şeylerin kullanılip harcanması"1, "yok etmek"2, "israf, ifrat ve harcamak" ${ }^{3}$ anlamlarma gelmektedir. Baudrillard'a göre tüketim, "üretimle yok etmek arasındaki aracı bir terimdir."4 Tüketim, gösterge, sembol ve işaretlerin de içinde olduğu sosyal ve kültürel bir olgu olarak da görülmektedir. ${ }^{5}$ Tüketici ise tüketim faaliyetini yapan ve "kişisel istek, arzu ve gereksinimleri için 'pazarlama bileşenlerini' satın alan veya alma kapasitesi olan gerçek bir kişidir." ${ }^{\prime 6}$ Tüketiciler, satın aldıklarıyla sosyal kimlik inşası gerçek-

1 “Tüketim", Türk Dil Kurumu, erişim: 1 Nisan 2019, http://www.tdk.gov.tr/index. php?option=com_gts\&arama=gts\&guid=TDK.GTS.5cb1af99a82563.73286365

2 Melek Coşgun, "Popüler Kültür ve Tüketim Toplumu”, Batman Üniversitesi Yaşam Bilimleri Dergisi 1/1 (2012): 844.

3 Mike Featherstone, Postmodernizm ve Tüketim Kültürü, trc. Mehmet Küçük, 3. Bask1 (İstanbul: Ayrıntı Yayınları, 2013), 51.

4 Jean Baudrillard, Tüketim Toplumu Söylenceleri Yapıları, trc. Hazal Deliceçaylı - Ferda Keskin, 5. Baskı (İstanbul: Ayrıntı Yayınları, 2012), 44.

5 Robert Bocock, Tüketim, trc. İrem Kutluk, 3. Baskı (Ankara: Dost Kitapevi, 2009) 13.

6 Coşgun, "Popüler Kültür ve Tüketim Toplumu”, 845. 
leştirerek, modern tüketim toplumlarında tükettikçe var olmaktadırlar. ${ }^{7}$ Belki bir mottoyu kullanımının dışında, bana ne/nasıl tükettiğini söyle, sana kim/ne veya hangi sinffta/statüde olduğunu söyleyeyim şeklinde değiştirerek, tüketimin aslında bir ilişki biçimi, sosyal arkadaşlık, statü ve kimlik inşası olduğu söylenebilir. Böylece çevresiyle fazla ilişkisi olmayan bir tüketici, sadece tükettikleriyle bile kendine sosyal statü veya kimlik oluşturabilir.

Tüketim ve tüketiciliği basit bir pazar alış-verişi faaliyeti olarak görmemek gerekir. Bocock, modern tüketicilerin fiziksel olarak pasif ama zihinsel olarak çok meşgul olduklarını; tüketimin sadece vücudun gereksinimlerini doyuran basit bir süreç olmaktan çıktı̆̆ını ve bunlardan dolayı yabancılaşma ve uzaklaşmanın modern tüketim kalıplarına girdiğini belirtmektedir. ${ }^{8}$ Böylece tüketim kavramı, kompleks sonuçlarıyla günümüz toplumlarının çözümlenmesinde etkili olmakta ve başta klasik sosyologlar olmak üzere birçok bilim insanın bu konuya yönelmesini sağlamaktadır.

\subsection{Marx'ın Kapitalizmi ve Tüketim İlişkisi}

Tüketimle girift bir ilişki içinde olan kapitalizm, "üreticilerin dolayımsız ihtiyaçların karşılamaktan ziyade, satış, mübadele ve kâr amacı güden bir ücretli emek ve meta üretimi sistemi" ${ }^{\prime \prime}$ olarak üretilen mal veya hizmetlerin metalaştırıldığı bir süreci içermektedir.

Meta, "alınıp satılabilen her şey" olarak özetlense de; geniş manada meta(laşma), daha önce ekonominin dışında olup bir market değeri olmayan servis, ürün veya ilişkilerin ekonominin içine çekilmesiyle bir market yani değiş-tokuş değeri kazanması olarak açıklanmaktadır. ${ }^{10}$ Marx, "toplumun en temel hücresi" olarak gördüğü metayı, kapitalist toplumsal yapının çözümlenmesinin merkezine koyarak, klasik iktisadın ötesine yerleştirmektedir. Böylece metanın değişim amaciyla üretilen bir şey olduğunu savunan Marx, kapitalizmin, her şeyi metalaştırarak, para aracılığıyla onları kullanım değerinin dışındaki değişim değeriyle de ürettiğini belirtmektedir. ${ }^{11} \mathrm{Bu}$ bağlamda Bocock, modern kapitalizmin kapitalistlerle değil, sermayeyle ilgili olduğunu

7 Bk. Vehbi Bayhan, “Tüketim Toplumunda Bireyin Ontolojik Mottosu: Tüketiyorum Öyleyse Varım", Sosyoloji Konferansları Dergisi Mustafa Erkal Özel Sayısı 43 (2011): 221-248.

8 Bocock, Tüketim, 58.

9 Gordon Marshall, "Suç", Sosyoloji Sözlüğü, trc. Osman Akınbay - Derya Kömürcü, (Ankara: Bilim ve Sanat Yayınları, 2014), 382.

10 İsmail Demirezen, Tüketim ve Din (İstanbul: Ensar Neşriyat, 2015) 40.

11 Karl Marx, Kapital, Kapitalist Üretimin Eleştirel Bir Tahlili, trc. Alaattin Bilgi, 2. Baskı (Ankara: Sol Yayınları, 1978), 1: 45-55. 
ve bu sermayeye sahip olanların güttüğü kâr amacının da yabancılaşmaya yol açtı̆̆ını ileri sürmektedir. ${ }^{12}$

Günümüz tüketim anlayışı, bir ürünün kullanım değeri veya işlevsel özelliğinden ziyade, o ürünün göstergesi veya markası gibi sembolik özellikleriyle tüketilmesine yönlendirmektedir. Böyle bir tüketim sürecinde, pazarlama stratejileriyle malların üzerindeki göstergeler, marka işaretleri de aktif rol oynamakta ve maddi nesnelerin tüketimi, yerini imajların ve markaların tüketimi biçimindeki "seyirlik tüketime" bırakmaktadır. ${ }^{13}$ Bu bağlamda tüketimin her zaman bir semboller ve göstergeler tüketimi olduğunu; modern toplumların tüketimci topluma dayandığını; bu sebepten günümüz toplumunun tüketim toplumu olarak nitelendirilmesi gerektiğini belirten Baudrillard, tüketim toplumunu; tüketimin öğrenilmesi toplumu, tüketime toplumsal bir biçimde alıştırılma toplumu olarak görmekte ve yeni üretim güçlerinin ortaya çıkmasıyla yeni ve özgül bir toplumsallaşma tarzı olarak açıklamaktadır. ${ }^{14}$

Tüketim kültürü ise metaların mübadele değerinin yok olduğu; malların kullanım işlevi yerine gösterge işlevinin ön planda tutulduğu; alışverişi yapılan, imrenilen, tüketilen şeylerin göstergelerden ibaret olduğu bir anlamı içermektedir. ${ }^{15}$ İnsanların kendilerinin ve başkalarının toplumsal konumlarını, tüketilen imajlar aracılığıyla algılamaya başladığı ve bir nesnenin değişim değerinin kullanım değerini örttüğü ${ }^{16}$ bu kültürde yaşayan birey, hayat tarzını bir yaşam projesi haline getirmekte ve ürünleri, giysileri, pratikleri, tecrübeleri, görünüşleri tercih ederken bir hayat tarzı oluşturmaya çalışmaktadır. ${ }^{17}$ Bu manada Debord, metaların şenlikli bir gösterinin aksesuarları haline gelerek yaşamlarımızı büsbütün işgal ettiklerini belirtmektedir. ${ }^{18}$

12 Bocock, Tüketim, 44.

13 M. Cem Şahin, "Postmodern Dönemde Tüketim Olgusunun Sosyo-Kültürel Analizi ve Yabancılaşma", Dini Araştırmalar 11/31 (2008): 189.

14 Baudrillard, Tüketim Toplumu Söylenceleri Yapıları, 87.

15 Zygmunt Bauman, Özgürlük, trc. Kübra Eren, 2. Baskı (İstanbul: Ayrıntı Yayınları, 2016), 82.

16 Şahin, "Postmodern Dönemde Tüketim Olgusunun Sosyo-Kültürel Analizi ve Yabancılaşma", 193.

17 Şahin, "Postmodern Dönemde Tüketim Olgusunun Sosyo-Kültürel Analizi ve Yabancılaşma", 180.

18 Guy Debord, Gösteri Toplumu ve Yorumları, trc. Ayşen Ekmekçi - Okşan Taşkent, 4. Bask1 (İstanbul: Ayrıntı Yayınları, 2012), 47-56. 
Orçan, tüketim kültürüne sahip toplumları, tüketim kültürünün nimetlerini sınırlı kullandıkları için -ki özellikle üretici olmaktan çok tüketici toplumlar olmaları sebebiyle- tüketici toplumlar olarak adlandırmaktadır. Bu toplumlar, yerli ve geleneksel tüketim tarzlarıla modern sonrası tüketim tarzları arasında sıkışmakta ve adapte süreci yaşamaktadırlar. ${ }^{19}$ Buna göre Türkiye, tüketici toplum görünümündedir. Ancak Demirezen, tüketim toplumlarındaki üreticiliğin olup olmamasına bakmamaktadır. Ona göre, tüketim toplumlarını diğer toplumlardan ayıran özellik, insanoğlunun en doğal aktivitesi olan tüketimin toplumu yönlendiren ve belirleyen bir güce dönüşmüş olmasıdır. ${ }^{20}$ Ayrıca kültür endüstrisinin yerel kültürle eklemlenerek fabrika bandında yer alması ve kültürel, yerel ve dini metaların buradan çıkarak tüketime sunulması, Türkiye'yi Orçan'ın tüketici toplumundan ayırmakta ve özetle Türkiye'nin bir tüketim toplumu olduğunu da göstermektedir.

\subsection{Tüketim Toplumu ve Din}

Dinin farklı özellikleriyle birçok tanımı mevcuttur. ${ }^{21}$ Ancak bu çalışma bağlamında değerlendirilecek Demirezen'in tanımına göre din; toplumsal hayata gömülü bir semboller sistemidir. Bu sistem insanoğlunda güçlü, kapsamlı ve uzun süre devam eden halet-i ruhiyeleri ve güdülenmeleri oluşturup, bunu genel bir varoluş düzeninin kavramlarını formüle etmektedir. Bunu, bu kavramlara gerçeklik elbisesi giydirerek yapmakta ve böylece söz konusu halet-i ruhiyeler ve güdülenmeler, kendilerine özgü bir biçimde gerçekçi olarak görünmekte ve toplumsal birliktelikler oluşturmaktadır. ${ }^{22}$

Dindarlığı, kısaca, kişinin kendini, mensubu olduğu inanç, değer, ibadetleri içeren sistemin tüm normlarına adayarak yaşaması veya buna çaba göstermesi olarak ifade edebiliriz. Tüketici davranışları açısından bakıldığında dindarlık olgusunun yönlendirici olduğu görülmektedir. Türkiye toplumu, dindarlık bakımından hem eğilimleri hem de davranışları ve fikirsel dünyalarındaki sonuçları bağlamında dindar ülkeler arasındadır. ${ }^{23}$ Dolayısıyladır

19 Mustafa Orçan, Osmanlı'dan Günümüze Türk Tüketim Kültürü, 2. Bask1 (Ankara: Harf Eğitim Yayıncılığı, 2008), 29.

20 Demirezen, Tüketim ve Din, 34.

21 Bk. Abdurrahman Kurt, "Sosyolojik Din Tanımları ve Dine Teolojik Bakış Sorunu”, Uludă̆ Üniversitesi Illahiyat Fakültesi Dergisi 17/2 (2008): 73-93.

22 Demirezen, Tüketim ve Din, 24.

23 Ali Çarkoğlu - Ersin Kalaycıoğlu, "Türkiye'de Dindarlık: Uluslararası Bir Karşılaştırma”, İstanbul Politikalar Merkezi (2009): 42. 
ki dindarlık, hem tüketicilerin Pazar anlayışlarında hem de pazarlamac1ların tüketici anlayışında etkilidir. ${ }^{24}$ Örneğin domuz etinin satın alınması Türkiye'deki tüketiciler tarafından Hristiyan dindarlığının yüksek olduğu ülkelere göre daha az tercih edildiğinden pazarlamacılar, bu ürünleri pek fazla sunmamaktadır. Buna karşın Kurban Bayramı'nda dini bir görev olarak, büyükbaş hayvan satın alımının diğer dinlerin yaygın olduğu ülkelere göre daha çok olduğu görülebilir. Ayrıca helal-haram yeme içme gibi giyinme vb. gündelik yaşam eylemleri de bireylerin veya toplumun bağlı olduğu yağın dine göre şekillenmektedir. Bu durumda dindarlığın tüketim toplumlarındaki tüketici seçimlerini etkilemede başat bir rolü olduğu söylenebilir.

\section{YABANCILAŞMA KAVRAMI}

Latince'deki "başkası", "yabancı" anlamina gelen "allenus" kökünden türetilen ve batı dillerine "kendinden geçme, benliğinin 'dış'ına çıkma" 25 olarak "alienation" biçiminde geçen yabancllaşma, yerli olmayan, ona bir biçimde uygun düşmeye $n^{26}$ anlamına gelmektedir. Bu anlamda bireylerin yaşamlarının kontrolünü kaybetmelerini, birbirlerinden veya belirli bir ortamdan uzaklaşmalarını ifade etmektedir. İnsanın, dünyaya, çevresine ve diğer insanlara yabancılaşmış olduğu fikri, bu kavramın temelini oluşturmaktadır. Yabancılaşma birçok şekilde açıklanabilmekle beraber, tüm yabancılaştırmaların kökeninde, insanın emeğinin sonucunda ortaya çıkardığg ürününe başkaları tarafından el konulması yatmaktadır. ${ }^{27}$ Kavram, başta Hegel olmak üzere birçok düşünür tarafından açıklanmaktadır. Ancak kapitalist sisteme bir tepki olarak sistematik bir biçimde ele alınmasının Marx ile gerçekleştiği söylenebilir.

Yabancılaşmanın insanı mekanikleştiren, metalaştıran ve sonunda köleleştiren rasyonalist uygarlık biçimine karşı oluşan bir başkaldırı simgesi olduğunu savunan Marx'a göre, bu durum dört boyutta gerçekleşmektedir. Birincisi; işçinin kendi emeğine olan yabancılaşmasıdır. Kapitalist sistem içindeki işçi; emeği sonucu ortaya çıan ürün üzerinde kontrol sağlayamamaktadır. Böylece işçinin emeği veya emeğiyle ürettiği ürün, işçi için giderek

24 M. Emre Çubukçuoğlu - S. Burak Haşılıoğlu, “Dindarlık Olgusunun Satınalma Davranışı Faktörleri Üzerine Etkisi", Tüketici ve Tüketim Araştırmaları Dergisi 4/1 (2012): 1-18.

25 Sibel Özbudun v.dğr., Yabancılaşma Ve... (Ankara: Ütopya Yayınevi, 2007), 16.

26 Mustafa Aydın, Güncel Kültürde Temel Kavramlar (İstanbul: Açlımkitap Yayınevi, 2011), 497.

27 Özbudun v.dğr., Yabancılaşma Ve..., 52. 
farklı bir durumu ortaya çlkarmaktadır. ${ }^{28}$ Isşçinin ürettiği ürün, kendilerinin değil, işverene veya üretim araçlarına sahip olanlara aittir. Pazara sürülen bu ürün, ona emek vererek üreten birey tarafından parayla satın alınmaktadır. İşçi, emek verip ürettiği ve sonrasında kendisine pazarda sunulan ürünü satın almak için gerek duyduğu paraya, yine çalışmak zorunda kalarak ulaşmaktadır. Yani işverene emeğini yine satmakta ve emek vererek ürettiği ürünü almak için yine emek vererek başka ürünler üretmektedir. Böylece pazardaki ürün, artık işçiye yabancılaşmakta ve işçi de emeğinin sonucu olan bu ürününe yabancılaşmaktadır. ${ }^{29}$

Yabancılaşmadaki ikinci boyut; işçinin üretim sürecinde kontrol imkânı bulamaması sonucu, üretim sürecine olan yabancılaşmasıdır. Birey için işi veya mesleği, sadece haftalık veya aylık ücret karşılığı verdiği ve maddimanevi güç harcadığı bir emek süreci değildir. İşçinin, bir ürünün üretim planlamalarına ve üretim sürecinin kontrolüne doğrudan imkân bulamaması, onun mekanik bir robot veya makineden farkının olmadığının açık bir işaretidir. Nitekim mekanikleşmiş bu düzen, egemen zihin tutumu olarak sıradanlığı, heyecansızlığı gerektirmekte ve bireyin yaşamındaki büyüleri yok ederek, insanı hesap edilebilir bir konuma götürmektedir. ${ }^{30}$ Marx, emeğin yabancılaşmasına sebep olan üretim sürecinin, insanların yaratıcılığını, yaşamsal niteliklerini ve doğaları gereği yaptıkları faaliyetlerini etkilediğini; işçileri üretim sürecinin bir çarkı haline getirerek, onları başkalarının istediklerini üretmek zorunda bıraktığını ve böylece insanları da üretim sürecinin hâkimi değil kölesi konumuna getirdiği için yabancılaştıklarını belirtmektedir. ${ }^{31}$

Marx'ın önem verdiği üçüncü yabancılaşma, doğaya yani insanın kendi doğasına yabancılaşması biçimindedir. ${ }^{32}$ İnsanların emeği sonucu ürettikleri nesne, onu üretene, ondan bağımsız ve ona yabancı olarak görünmektedir. Emeğin ürünü, emek sahibine yabanclaştıran süreç neticesinde işçiden ayrılmaktadır. Verilen veya sahip olunan emek, bu noktada, iş̧̧inin doğasının

28 Gökhan Ofluoğlu - Ozan Büyükyılmaz, "Yabancılaşmanın Teorik Gelişimi ve Tarihsel Süreç İçinde Farklı Alanlarda Görünümleri" Kamu-İş Dergisi 10/1( 2008): 126.

29 Karl Marx, "1844 El Yazmaları", Yabancılaşma, trc. Barışta Erdost, 4. Baskı (Ankara: Sol Yayınları, 2010), 22.

30 Fritz Pappenheim, Modern İnsanın Yabancılaşması Marx'a ve Tönnies'ye Dayalı Bir Yorum, trc. Salih Ak (Ankara: Phoenix Yayınevi, 2002), 32.

31 Marx, "1844 El Yazmaları", 24-25.

32 Marx, "1844 El Yazmalar1”, 26-27. 
bir parçası olmaktan çıkmaktadır. Artık çalı̧̧mak yani emek harcamak, sonucunda yabancllaşan bir ürüne götürdüğü için işçiyi mutlu etmemektedir. İşçinin doğası gereği yaptığı ussal, nitelikli, bilinçli ve istekli çalışma eylemi, artık hayvanların içgüdüsel olarak yaptığı bir eylemden farklılaşmamakta ve işçileri fiziksel ve zihinsel yönden yok etmektedir. Bu anlamda çalışmaktan ziyade çalışmamak yani yabancılaşmaya götüren bir eylemi yapmanın aksine o eylemsel süreçten uzak kalmak, onu kendine/doğasına geri getirmektedir. Bu da aslında insanın doğasına aykırı ve yabancı bir durumdur. ${ }^{33}$ Özetle, insanlar, doğaları gereği günlük yaşamlarında hatta ömürleri boyunca, yaşamlarını idame ettirebilmek için yeme, içme, barınma ve giyim ihtiyaçları dışında olmazsa olmaz bir şeye gerek duymamaktadırlar. Ancak kapitalist sistemin bir çarkı olan insan, sürekli üretmek ve ihtiyacı olamamasına rağmen ürettiklerini tüketmek hususunda yönlendirilmektedir. Bu durumda kendisine engel olamayan insan, kendisine ve egemen olmaya çalıştığı doğasına yabancılaştırılmaktadır.

Son olarak insanın kendi türüne olan yabancılaşması, dördüncü boyutu oluşturmaktadır. İnsanın, emek vererek ürettiği ürününe ve üretim sürecinin etkileri neticesinde oluşan doğasına yabancılaşması, kendi türündeki insanlara yani insanın insana yabancılaşmasını dolaysız olarak doğurmaktadır. ${ }^{34}$ Nitekim yabancılaşma, yalnızca işçiler ve onların emeği arasındaki ilişkiyi içermemekte; ayrıca toplumdaki bireyler arasındaki ilişkiyi de şekillendirmekte ve çarpıklaştırmaktadır. İnsanlar, diğer insanlarla işbirliği içinde ortaklıklar yapabilecekken, aksine onları rakipleri olarak görmekte ve yalnızlaşmaktadırlar. Böylece kapitalist sistemin mantığıyla çarpıklaşan toplumsal ilişkiler, insanların kendi türündeki diğer insanlarla ilişkisini etkileyerek, yine kapitalist sınıflar aracılığıyla gerçekleşmektedir. ${ }^{35}$

Marx'ın kapitalist sistemi çözümlemede kullandığı yabancılaşma kavramının, günümüz tüketim toplumlarındaki kapitalist görünümlerle de ilişkili olduğu ve bu toplumları analiz etmemize imkan verdiği gösterilebilir.

\subsection{Tüketim Toplumu ve Yabancılaşma}

Tüketim toplumundaki tüketici kodların etkisiyle kendisine hızla yabancılaşan bireyler, suni ihtiyaçlarını karşılamak ve refahını sağlamak için üretim sürecinin kölesi durumunda kalmakta ve bu haliyle sürekli kendisini

33 Marx, "1844 El Yazmalar1", 28-29.

34 Marx, "1844 El Yazmaları”, 29.

35 Dan Swain, Yabancılaşma Marx'ın Teorisine Bir Giriş, trc. Hande T. Urbarlı (İstanbul: Durak İstanbul Yayıncılık, 2013), 50-51. 
yenilemeye çalışan bir birey haline dönüşmektedir. Bu durumu Baudrillard şu şekilde değerlendirmektedir ${ }^{36}$ :

"Modern insan hayatın giderek daha az emek içinde üretimle, ama giderek daha fazla kendi ihtiyaçlarının ve refahının üretimi ve sürekli yenilenmesiyle geçirir. Modern insan, tüketimci potansiyelliklerinin ve kapasitelerinin tamamin seferber etmeye odaklanmalıdrr. Eğer bunu unutursa, kendisine mutlu olmama hakkna sahip olmadığ kibarca ve ısrarla hatırlatılır. Dolayısıyla modern insanın edilgin olduğu doğru değildir. Modern insanın sergilediği ve sergilemek zorunda olduğu sürekli bir etkinliktir. Aksi halde modern insan sahip olduğuyla yetinme ve toplumdışı olma riskiyle karşı karşıya kalacaktır."

Toplumdışlılık, oluşturulmuş bir statüye ve sürece işaret etmektedir. Modern tüketim toplumlarındaki birey, toplumun verdiği statüye, göreve ve normlara uygun davranmaya çalışmakta ve kendisi için buna çaba göstermektedir. Toplumun içinde kalmak, kendisine ait statüyü korumak veya yükseltmek için bazı tüketim alışkanlıklarını edinmek (moda takibi, gösteriş̧̧i veya sembolik tüketim gibi), bireylerin toplumdan dışlanmamaları, toplum içerisinde ayakta durabilmeleri ve varlığını kabullendirebilmeleri için gerekli olan ipuçlarını vermektedir.

Üretim sürecinde bulunamayan, emeğinin sonucunda ortaya çıan metaları sahiplenemeyen, doğayı sürekli tüketme amacıyla kontrol altında tutmaya çalışan tüketim toplumundaki bireyler, kendi yeteneklerini, varlıklarını ve benliklerini unutmakta, kendilerine yabancılaşmakta ve tüketmek için yaşamaktadırlar.

Baudrillard, tüketim toplumlarındaki tüketimi, bireyin kimlik inşasını sağlayan bir vitrin olarak görerek, bireyin kendisiyle yani öznesiyle ilişkisindeki yabancılaşmasına dikkat çekmekte; bireyin yabancılaştırıcı bir merci tarafından kendi kendisine yabancı hale getirildiğini savunmakta ve bundan dolayı tüketimi oyuncul görmektedir. Ayrıca tüketimdeki oyunculluğun giderek kimliğin acıklı yerine geçtiğini vurgulayan Baudrillard, bu oyunculluğun tüketici bireyi, taklide, kendisinin dişındaki bir kendiliği oluşturmaya, yapay haz ve mutluluklarla yaşamını sürdürmeye götürerek yabancilaşmasına neden olduğunu belirtmektedir. ${ }^{37}$

Gerçekliğin yerini suretlerin aldığı kapitalizmin bugünkü konumu, artık suretlerin (marka değeri, sembol) tüketilme aşamasına geçmiştir. ${ }^{38}$ Bura-

36 Baudrillard, Tüketim Toplumu Söylenceleri Yapıları, 86.

37 Baudrillard, Tüketim Toplumu Söylenceleri Yapıları, 232-235.

38 Şahin, "Postmodern Dönemde Tüketim Olgusunun Sosyo-Kültürel Analizi ve Yabancılaşma", 187. 
daki birey, izlediği reklamlarla kendine yeni bir kendilik yani öznelik satın almakta; televizyon ve medyadaki mutlu aileleri taklit ederek ki özellikle onlar gibi yaşamak ve tüketmek eğilimine yönelerek, hayatını ve ailesini özündeki kodlardan ayırmakta ve tüketim kodları ve sahte mutluluk kodlarıyla kendini donatmaktadır. Netice itibariyle kendisine, bedenine, ruhuna, yeteneklerine, emeğine, çevresine, doğaya ve bunlarla beraber toplumsal yaşamını yönlendiren dinine yabancılaşmaktadır.

\subsection{Din ve Yabancılaşma}

Bu çalışmanın temel taşları, Marx'ın yabancılaşma kavramı üzerine yerleştirilmektedir. Marx, gerek kendi döneminin gerekse kapitalist sistemin yabancılaşma boyutlarını göstermektedir. Nitekim bu çalışma, İslam'da veya diğer dinlerde yabancılaşma kavramını ortaya koymaya çalışmamaktadır. Fakat hem genel manada yabancılaşma kavramının dinle ilişkisini ortaya koyabilmek hem de tüketim toplumunun Türkiye örnekleminden yabancılaşma ve din ilişkisi analizini yapılabilmek için İslam ve diğer dinlerde, bireylerin dine yabancılaşması tezahürlerine değinmek gerekmektedir.

Özellikle batı düşünce sisteminde yabancılaşmaya ilişkin durumlar, Eski Ahit'e dayandırılarak, orada anlatılan putperestlikle açıklanmaktadır. Bu yönde putperestlik, tapınılan putların insan elinden ve emeğinden çıan bir nesneye tapınılması olarak ele alınmaktadır. ${ }^{39}$ Böylece putperestlikte, insan kendi elinden ve emeğinden çıkan nesnelere tapınmaktadır. Bu durumda, insan hem kendine yabancilaşmakta, hem de emeği sonucunda ortaya çıkan nesnesine artı değer atfederek yani kutsallık ekleyerek, nesnesine yabancılaşmaktadır. Kısaca, insan ya kendi yarattığı putun altında ezilerek kendisine ve nesnesine yabancllaşmakta ya da kendi üstüne kıvrılarak, kendi ağırlığı altında ezilerek kendisine, hemcinslerine ve temsil ettiği güce karşı yabancılaşmaktadır..$^{40}$ Burada, insanın kendi elleriyle ürettiği, fakat sonrasında fetiş bir bağ oluşturarak kendi ürününe yabancılaşması durumunun, Marx'ın emeğin ürününe yabancılaşması boyutuyla ilgili olduğu söylenebilir.

Hristiyan dünyasında yabanclaşmayla ilgili çeşitli açıklamalar vardır ve birçoğu insanın kendine ve dünyasına yani var olduğu mekâna yabancılaşması üzerinedir. İlk insan Hz. Âdem'in şeytanın kandırması sonucu işlediği “ilk günah" ile başlayan, Hz. İsa'nın çarmıha gerilmesi ve Tanrı'nın 
oğlu olduğu inancının yani Hz. İsa'nın Tanrısal özelliklerle kutsanmasıyla devam ede gelen bir yabancılaşma durumu gerçekleşmektedir. Fakat Tanrı'ya bir başkaldırı olarak görülen bu yabancılaşma, sonsuza kadar sürmeyecek ve kiliseye yönelindiğinde ortadan kalkacaktır. ${ }^{41}$

İlk günah konusu, İslam dininde yabancılaşmanın faklı bir yorumuyla ele alınmaktadır. Hz. Âdem, yaptığı bir eylemle cennetten dünyaya gönderilmiştir. Böylece insanın asıl mekânı olan cennetten ayrılmasıyla yabancı bir mekâna gelmesi ve insanın Tanrıdan kopması, ondan uzak kalması veya ayrı düşmesi asıl yurdundan çıkarılması sonucunu doğurarak, dinine yabancılaşmasının bir sebebini oluşturmaktadır. İnsanı yabancılaşmadan kurtaracak yol ise peygamberlere yönelmekle gerçekleşecektir. ${ }^{42}$

Kur'an'da yabancılaşmayla ilgili konulara bakıldığında, insanın fitrat gereği nankör ${ }^{43}$, cimri $^{44}$, zalim ${ }^{45}$, cahil ${ }^{46}$, gaflet içinde ${ }^{47}$ gibi olumsuzluklara sahip olduğu ifade edilirken; yaratılanların en güzeli ${ }^{48}$, kâinatın ona hizmete sunulduğu varlık ${ }^{49}$, Allah'ın halifesi ${ }^{50}$ gibi yüceltici özelliklerine de yer verilmektedir. Kur'an'a göre insan, kökünde yabancılaşmış bir varlık değil, aksine yabancılaşma problemlerini aşabilecek zengin bir potansiyele sahip, yetkin bir varlıktır ki fitratındaki bu olumsuz özellikleri, onu yaşamı boyunca duyarlılık içerisinde olmasını sağlamak üzere ilahi uyarılar olarak mevcuttur. ${ }^{51}$ Ayrıca Kur'an, gurur ve kibrin ${ }^{52}$, ölçü ve tartıda hile yapmanın ${ }^{53}$, ticaret ahlakının çıkar için kullanılmasının ${ }^{54}$ yabancılaşmaya neden olacağını

41 Tuncar Tuğcu, Yabancılaşma Problemi Hıristiyanlığın ve Marksizmin Kökleri (Ankara: Alesta Yayınevi, 2002), 83-87.

42 Ali Bulaç, İnsanın Özgürlük Arayışı, (İstanbul: İnkılap Kitapevi, 2015), 219-222.

43 Nasr, 110/6.

44 Maide, 5/137.

45 Al-i İmran, 3/72.

46 A'raf, 7/179.

47 Asr, 103/2.

48 Tîn, 95/4.

49 Mülk, 67/15.

50 Bakara, 2/30.

51 Muhammet Çakmak, “Yabancılaşma Kavramı Üzerine Bazı Değerlendirmeler ve Kur'an'ın Yabancılaşma Kavramına Bakışı", Fırat Üniversitesi İlahiyat Fakültesi Dergisi, 1(1996): 306.

52 Al-i İmran, 3/87.

53 Mutaffifinn, 83/1-3.

54 Bakara, 2/188. 
da ifade etmektedir. Bunlara ek olarak Ma'un Suresi incelendiğinde, yabancllaşan insanın özellikleri sıralanmaktadır. Yabancılaşan insanlar, dini yalanlar, öksüzü itip kakar, yoksulu doyurmada önayak olmaz, namazlarının değerini bilmez, gösteriş için ibadet eder ve en ufak bir yardımı esirgemektedirler. ${ }^{55}$ Bu durumu Çakmak şöyle özetlemektedir:

"Kur'anın nazarında insan, paylaşmayan, karşıllksız harcamayan ve merhametli olmayan bir yapıya büründüğ̈̈ zaman ilahi mesajla bağlarını koparır. Çünkü $O$, hayatı ve yaşadığı topluma karşı yabancilaşmıştır. Bu çerçevede Kur'an'da yabancılaşma, insanın yaşadığı toplumdaki münasebetleriyle ilişkilendirilmektedir. Şu halde Kur'an, yabancilaşmadan kurtulabilmenin yolu olarak toplumsal insan olmayı gerekli görürken, bir taraftan da insani ilişkilerimizde, bencil ve tutkularımızın esiri olarak davranmamayı öğütlemektedir."

Bu ifadelerden yola çıkarak, aslında bu durumun Marxist perspektifte, adı koyulmamış yabancılaşma olduğu söylenmelidir. Bu anlamda özellikle tüketimsel bir eylemde, dini değer, ritüel ve mekânlarında bir uzaklaşma, kopma, anlam kayması veya başkalaşma varsa bunun tanımı dine yabancılaşma olarak ifade edilebilir.

\section{DİNE YABANCILAŞMA}

Marx, dini düşünce ve kurumları insanların yarattığını; dinin mevcut ekonomik ve sosyal eşitsizlikler karşısında insan için bir teselli aracı olduğunu; bu inancın kaynağının gündelik yaşamda tecrübe edilen yabancılaşma olduğunu; sadece komünist bir toplum düzeniyle bu yabancılaşmanın üstesinden gelinebileceğini ve dini düşünce ve kurumların bu şekilde ortadan kalkacağını ifade etmektedir. ${ }^{57} \mathrm{Bu}$ açıklamadan anlaşılacağı üzere Marx, dinin yabancılaşma kaynaklı bir inanç sistemine sahip olduğunu belirtmektedir.

Fromm, Marx'ın insanların yabancılaşması kavramıyla dindeki günah kavramının çok benzeştiğini; her ikisinin de "insana karşı" ve "insana yaramayan", yani onu bozan olgulara verilen isim oldukların ve her ikisinin de insanı gerçek hedefinden saptırıp, ayrılıkçı anlayış doğrultusuna sürüklediğini ifade etmektedir. ${ }^{58} \mathrm{Bu}$ manada dine yabancılaşma konusu Marxist perspektifte açıklanabilir bir durumdur. Böylece bu çalışma için öngörülen dine yabancılaşma, Marx'tan hareketle, tüketim toplumundaki dini değer,

55 Ma'un, 107/1-7.

56 Çakmak, "Yabancılaşma Kavramı Üzerine Bazı Değerlendirmeler ve Kur'an’ın Yabancılaşma Kavramına Bakışı", 308.

57 Jonathan Wolff, Why Read Marx Today, (New York: Oxford University Press, 2002), p. 102.

58 Fromm, Marx'ın İnsan Anlayışı, 11. 
ritüel ve mekânların metalaşmasıyla ortaya çıkan yeni bir boyut ve durum olarak bireyin dine yabancılaşması üzerinedir.

Bir tanımlama yapmak gerekirse dine yabancılaşma; dinin, tüketim toplumu ile etkileşime girerek metalaştı̆̆ı anda kendi değer, ritüel ve mekânlarında meydan gelen orijinal/hakiki/merkezi anlamından kopma, uzaklaşma ve başkalaşmasının bir sonucu olarak bireye yabancılaşması durumudur. Bu tanım itibariyle, Türkiye toplumunun tüketim toplumu olması neticesinde, dinin burada tüketim toplumunun kodlarıyla etkileşime girerek ve metalaşarak, tükettirmek için bir kâr aracına dönüştüğünü; metalaşan dinin öz, orijinal, kök anlamında kopmaların gerçekleştiğini; dini değer ve ritüellerde ise dinin merkezinden uzaklaşmasına ve Marx'ın yukarıdaki dört yabancılaşma boyutuna ek olarak, bireylerin dine yabancılaşmasına yol açtı̆̆ı görülebilir.

\subsection{Tüketim Toplumunda Metalaştırılan Din}

Tüketim toplumunun etki ettiği noktada din, çoğulcu bir durumla karşılaşmaktadır. Dini çoğulculuk, dini geleneklerin herhangi bir grubun elinde bulunmaması gibi yapısal değişmeler nedeniyle din-toplum ilişki biçiminin değişmesiyle ilgilidir. Çoğulcu yapıda bireyin birden çok varoluşsal dünyadan birini tercih edebileceği alternatif dünya inşa etme durumun var olması durumunda, din, satın almak zorunda olmayan müşteriye satılmaktadır. ${ }^{59}$ Bununla beraber, çoğulcu durum, her şeyden önce bir pazar konumundadır ve burada dini kurumlar birer teşhir merkezleri haline gelirken, dini gelenekler ve değerler de tüketici malları haline dönüşerek metalaşmaktadır. Nasıl olursa olsun bundan dolayı hatırı sayılır ölçüde dini aktivite, pazar ekonomisinin mantığına göre belirlenmeye başlamaktadır. ${ }^{60}$ Böylece, tüketim toplumunun sunduğu yaşam tarzının etkili olması ve dinin pazar ekonomisine girmesiyle dini metalaşma örnekleri de görülmektedir.

Dinin pazar ekonomisinde kâr kazandıran bir meta olarak kullanılmasıyla ilgili çalışmalar birkaç yüzyıl önceye dayanmaktadır. ${ }^{61}$ Özellikle "rasyonel seçim teorisi" bazı düşünürler tarafından dine uygulanmaktadır. ${ }^{62}$ Postmo-

59 Abdülkadir Zorlu, "Batılı Bir Yaşam Tarzı Olarak Tüketim: Türkiye'de Tüketim Ürünlerinin ve Kültürünün Tarihsel Gelişimi", Hacettepe Üniversitesi Sosyolojik Araştırmalar E-Dergisi (2003): 7.

60 Peter Ludwig Berger, Kutsal Şemsiye Dinin Sosyolojik Teorisinin Ana Unsurları, trc. Ali Coşkun, 4. Baskı (İstanbul: Rağbet Yayınları, 2011), 241-242.

61 Bk. Peter L. Berger and et al., Religious America Secular Europe? A Theme And Variations, (Hampshire: Ashgate Publishing Limited, 2008).

62 Bk. Mehmet Ali Kirman, "Rasyonel Seçim Kuramı", Kahramanmaraş Sütçü İmam 
dern dönemdeki dini çeşitlilik, dini seçeneklerin artmasına neden olmakta ve bireylerin istedikleri dini tercih etme yelpazesini genişletmektedir. $\mathrm{Bu}$ dönemde, seçim yaparken rasyonel davranan bireyler, kendilerine göre getirisi (haz, mutluluk, korunma duygusu, para, evlilik, prestij, grup aidiyeti gibi) en yüksek olanı tercih edebilirler. ${ }^{63}$

Bireyler hangi dini, mezhebi veya dini grubu tercih edeceklerini, ne sıklıkla ve hangi şekilde dini aktivitelere ve gruplara katılacaklarını kendileri belirleyebilmekte; zamanla dini tercihlerinde önemli ölçüde değişiklik yapabilmekte veya dinlerini değiştirebilmektedirler. ${ }^{64} \mathrm{Bu}$ durum özellikle son çeyrek yüzyılda ortaya çıkan "yeni dini hareketler" 65 ile tüketim toplumuna eklemlenerek günümüzde "açık büfe din" veya "kafeterya dini" çıkmaktadır. Açık büfe din olarak da tabir edilen sosyal durumda, bireyler kendi istek ve arzularına göre yemek seçer gibi din veya dini semboller tercih edebilmektedirler. Dinler ya da dini değerlerin tüketim metasına dönüştüğü bu durumda, bu metaları satın alan veya seçen bireyler için bu dinler ve değerlerinin, renkleri farklı araba çeşitlerinden bir farkı kalmamaktadır. ${ }^{67}$ Böylece bu kesime ait bireyler, dinin metalaşan görünümünü satın alarak tüketicilikte yeni bir sınıfı oluşturmaktadırlar: din tüketicileri. Din tüketicileri, böyle bir pazarda çeşit çeşit dini değer, ritüel ve mekânları satın alarak, dinin veya pazardaki dinlerin orijinal anlamlarının kaymasına, merkezi anlamlarından uzaklaşmasına sebep olmakta ve Marxist manada kendi ürettiği emeği fetişleştirmesi açısından bireylerin dine yabancılaşmasına neden olmaktadır.

Üniversitesi İlahiyat Fakültesi Dergisi 22 (2013): 66-98; Adnan Selman - Ramazan Uçar, “Dini Tercihleri Anlama ve Açıklanmaya Farklı Bir Yaklaşım: Rasyonel Seçim Teorisi", Toplum Bilimleri Dergisi 5/10(2011): 91-110; Laurence R. Iannaccone, "Rational Choice Theories of Religion: Summary and Assesment", Rational Choice: Framework For The Scientific Study of Religion, Ed. L.A. Young (New York: Routledge, 1997), 25-44.

63 Birsen Banu Okutan, Türkiye'de Popüler Kültür Din ve Kadın Marjinalizasyondan Entegrasyona (İstanbul:, Düşün Yayıncılık, 2013), 50.

64 Laurence R. Iannaccone, "Voodoo Economics? Reviewing The Rational Choice Approach to Religion", Journal for the Scientific Study of Religion, 34/1 (1995): 77-78.

65 Bk. Niyazi Akyüz, İhsan Çapçıŏlu, “Dini Gruplar ve Yeni Dini Hareketler”, Din Sosyolojisi El Kitabı, Ed. Niyazi Akyüz, İhsan Çapçığlu (Ankara: Grafiker Yayınları, 2012), 507-576.

66 Bk. Mara Einstein, Brands of Faith: Marketing Religion in a Commercial Age (New York: Routledge, 2008); Ted G. Jelen, Sacred Markets, Sacred Canopies: Essays on Religious Markets and Religious Pluralism (Maryland: Rowman \& Littlefield Puplishers, 2002).

67 İsmail Demirezen, "Tüketim Toplumunun Oluşumu ve Din ile Etkileşimi", Dinbilimleri Akademik Araştırma Dergisi 10/3 (2010): 107. 
Kurgusal bir örnekle; din tüketicisi, inanç ihtiyacını karşılamak için pazara gider ve İslam'dan tevhid inancını sepetine koyar; bağışlanma ihtiyacı için Hristiyanlıktan günah çıkarma ritüelini ekler; yeme-içme alışkanlıkları için Yahudilikten kaşer/koşer listesini edinir; gündelik yaşamın stresiyle başa çıkabilmek adına Budizm'den yoga ve meditasyonu tercih eder ve kendisine bireysel bir din veya dini inanç, ritüel, değerler sistemi oluşturmuş olur. Böylece din tüketicisi, dinin kendisine zor gelen taraflarına maruz kalmadan, dünyada sıkıntı çekmeden, din veya dini inanç, değer vd. ihtiyaçlarını gidermektedir. Bu durum marketten bir şişe su almakla aynıdır. Çünkü suyun hangi marka, boyutta ve şişede olmasını istiyorsanız ona göre seçim yapabilirsiniz. Hatta istenilirse din tercihi yapmadan, bilgi edinmek ve yaşam biçimini öğrenmek için haftalık, aylık veya bir süreliğine o dine mensup kişilerce, tüketici tarafından tercih edeceği düşünülen din yaşanılabilir, ibadetleri eda edilebilir. Bazı günlerde veya haftalık, oruç tutarak, namaz kılarak Müslüman gibi yaşamanın nasıl bir şey olduğu tadılması için paketler sunan, kültür turizmi adında çeşitli geziler vardır. Bunlardan birinde; "İstanbul'da bir aylı̆̆ına Müslüman olun: günde beş kez ve hızlı bir şekilde dua edin" başlı̆̆ıla Müslümanlığı tanıtmak üzere tanıtımlar sunulmaktadır. Bu tanıtımlar, sadece Müslümanlık için değil; "Bir Aylık Yahudi" ve "Bir Aylık Keşiş" gibi farklı paketleri de içermektedir. ${ }^{68}$ Bu durum, tüketim kültüründeki hiçbir şeyi kaçırmama, her şeyin tadına bakma tutumunun neticesinde farklı dinlere ve dini yaşamlara bireylerin ulaşmalarını sağlamakta ancak bir yandan da dini değer, ritüel ve mekânları pazar tezgahına sermektedir.

\subsection{Dini Ritüel ve Mekânlara Yabancılaşma}

Tüketimin, her kesimden ve her inançtan bireyleri tüketici sınıfına sokma öğretisi, inananları farkında olmadan dini ritüellere ve mekânlara yabanc1laştırmaktadır. İslam dininde önemli bir yeri olan hac ve umre ritüellerinde, kapitalist tüketim kodlarının etkisiyle bir metalaştııılma durumu gerçekleşmektedir. Bu metalaştırılma, hac ve umrenin gerek hakiki dini anlamlarında gerekse eda edildikleri mekân veya yerlerin ilahi mesajlarında, bireylere yönelik bir başkalaşmaya neden olmaktadır.

Hac ve umre organizasyonlarındaki VIP özelliği ile özel jiplerle gezdirilen, Kâbe manzaralı ve açık büfe yemek ve içecekleri olan bol yıldızlı otellerde ibadet yapmak, ayrıcalı̆̆ın ve üstünlüğün bir işareti olmaktadır.

68 "Be Muslim for a month in Istanbul: pray five times a day and fast", The Guardian, erişim: 2 Nisan 2019, https://www.theguardian.com/travel/2011/apr/21/muslim-formonth-istanbul-turkey 
Örneğin lüks hac ve umre alanında hizmet veren bir firmanın yetkilisi, bir röportajda kendi şirketlerini şöyle tanıtmaktadır:

“... araçlar son model oluyor. 50 kişilik otobüsleri 28 kişilik özel araçlara dönüştürdük. Insanlar transfer esnasında rahat olsun diye bu araçlara en fazla 20 kişi alıyoruz. Ziyaret yerlerine en yakın otellerde konaklama yapilıyor. İsteyenlere 5 yildizlı Kabe gören odalarda konaklama şansı sunuyoruz. Normal şartlarda bir hacıya tabldot yemek verilirken, özel turları seçenler sabah, öğle, akşam açık büfeden yemek yiyebiliyor." Arafat'ta da Hac Bakanlığı'nın tahsis ettiğgi çadırlar yerine, 5 yıldızlı, klimalı çadırda misafirlerin ağırlandığııı... "Orada yemekler yine 5 yıldızlı bir otelin aşçıları tarafindan hazırlanıyor. Tura özel olarak hazırlanan alanlarda özel tuvalet ve özel banyolar da bulunuyor...Hac öncesi yapılan toplantı da Çıră̆an Sarayı'nda gerçekleştiriliyor... Uçuşlar business class yapılıyor. Suit odalarda konaklanlıyor. Medine'de Mescidi Nebevi ve Mekke'de, Kabe gören odalarda kalınıyor. Transferler büyük ciplerle să̆lanıyor. Gruplara kulaklık sistemleri üzerinden bilgi veriliyor. Özel ne isteniyorsa ayarlaniyor." 69

Hac ve umre ibadetleri, insanları eşitleme ve kulluklarının dışındaki farklılıklarını önemsizleştirme üzerine kuruluyken bu tür organizasyonlarla sınıf farklılığına ve üstünlüğünü vurgulamaya ve tüketim toplumuyla dini hassasiyet arasındaki bir ironiye işaret etmektedir. ${ }^{70}$ Bu durum, din ve dindarlık üzerinden maddi veya manevi çıkar elde etmek için dini eylemlerin samimi dindarlık objesinden samimi olmayan veya en azından istismar edilen süjeye dönüşümü mahiyetinde bir din istismarına işaret etmektedir. Din istismarı veya sömürüsünü yapanlar, maddi ve manevi çıkarları uğruna gerçekleştirdikleri davranışlarını, insanlara iyi göstermek, haklılaştırmak veya izah etmek için bazı kılıflar uydurmakta ve dini olarak meşrulaştırmaktadırlar. ${ }^{71}$

Reklam ve medya üzerinden tanıtımı yapılan bu tür organizasyonlar, tüketicilere ibadet kolaylığı ve paket servis gibi imkânları sunsa da; ibadetin özünden bir kopuşa, dini değerlerin başkalaşmasına götürmektedir. Ayrıca hac ve umrenin dini bir gereği yerine getirme amacından turistik gezi amacına doğru dönüşümü ve değişimi gerçekleşerek, dini mekânların manevi anlamını da sömürmekte ve bireylerin dine yabancılaşmasına neden olmaktadir.

69 "VIP Hac butik umre", Hürriyet Gazetesi, erişim: 2 Nisan 2019, http://www.hurriyet. com.tr/ekonomi/vip-hac-butik-umre-40362973

70 Demirezen, Tüketim ve Din, 91.

71 Ejder Okumuş, Dinin Meşrulaştırma Gücü (İstanbul: Özgü Yayınları, 2005) 68-70. 
Dini duyguların ve ibadetlerin üst seviyede yaşanıldığı veya yaşanılmaya çalışıldığı bazı zaman dilimleri vardır. İslam dini özelinde bunların başında, Ramazan ayı gelmektedir. Müslümanlar, Ramazan gelmeden çeşitli ihtiyaçlarını karşılamak üzere bazı hazırlıklar yapmaktadırlar. Ancak Ramazana has olan ihtiyaçların tüketim toplumu içinde nasıl bir biçimde istismar edildiği ve Ramazanın kendi ritüellerinde bulunmayan aşırı veya gösteriş̧̧i tüketimin ne ölçüde revaçta olduğuna dikkat edilmelidir. Bu konuda Okutan, geniş bir analizle Ramazanın tüketim toplumundaki görünümünü ve metalaşmasını popüler kültür çerçevesinde işlemektedir. Okutan'a göre; tüketim toplumu pek çok özel gün ve gecelerin değerlerini metalaştırdığı gibi Ramazan gibi bir aylık süreci ve ritüellerini de piyasa kurallarına uydurmakta ve pazarın döngüsüne göre yeniden ele almaktadır. Ramazan, gazete ve dergilerde işlenerek çeşitli iftar ve sahur mekânlarında sunulmakta; medyada çeşitli ramazan ekleri, hediyeler, dini kitaplar verilmekte; bazı bankalar Ramazana özel faiz indirimleri veya oranları uygulamakta; alışveriş merkezlerinde ramazan etkinlikleri düzenlenmekte ve bu durumun sonucunda Müslümanlar için dini bir kurtuluş ve fırsat ayı olan Ramazan, tüketim toplumunun kodlarıyla bezenerek tüketmek için bir fırsat ayına dönüşmektedir. ${ }^{72}$ Böylece bireyler, dini inançları gereği bazı eylemlere yönelmekte ancak bu eylemlerin tüketim kodlarıyla sunulmasıyla farkında olmadan kapitalist çarkın bir dişlisi olarak din tüketicisi sınıfına girmektedirler. Böylece bireyin metalaştırılan dini değer ve ritüellere yabancılaşması gerçekleşmektedir.

\subsection{Gösterișçi Dindarlık ve Yabancılaştırılan Tesettür}

Tüketim toplumlarında tüketimin öznesi artık göstergeler düzenidir. Göstergeler düzeni, bir vitrin olarak toplumsal statülerin belirlenmesine yani bireylerin hangi vitrinde olduklarına etki ederek, onları göstergeler tüketiminin oyunculuğuna itmektedir. Tüketimin bu oyunculuğu, giderek kimliğin trajikliğinin yerine geçmekte ve birey, kimlik oluşumunu bu oyunculluk üzerinden tamamlamaktadır. ${ }^{73}$ Yani birey, toplumsal kimliğini, bulunduğu sınıftaki vitrin üzerinden tanımlamaktadır. Bu durumu Veblen, gösteriş için mal alımı anlamında "gösterişçi toplum" olarak nitelemekte ve bu kesimi, zamanın üretici olmayan tüketimini yaptıkları için aylak sınıfı olarak adlandırmaktadır. ${ }^{74} \mathrm{Bu}$ sınıfın süreklilik arz eden tüketimi, israfla tüketim

72 Okutan, Türkiye'de Popüler Kültür Din ve Kadın Marjinalizasyondan Entegrasyona, 85-93.

73 Baudrillard, Tüketim Toplumu Söylenceleri Yapıları, 231-232.

74 Thorstein Veblen, Aylak Simfin Teorisi, trc. Zeynep Gültekin - Cumhur Atay (İstanbul: Babil Yayınları, 2005), 44. 
yaptığı sonucunu çıkarmaktadır. Aslında bu durum, itibarlı olabilmek için müsrif olabilmeyi öngörmektedir. Yani aylak sınıfın veya gösteriş toplumunun bir üyesiysen ve itibarın varsa müsriflik kaçınılmaz olarak vardır. ${ }^{75}$ Işaret değeri daha yüksek olan tüketim mallarını elde eden birey, böyle bir sistemde daha yüksek konumu elde eder ki aslında metaları kendilerine sunacakları farklıklar için satın alırlar. Bu durum insanın kendisine tamamen yabanc1laşmasını sağlayan önemli faktörlerden birini açığa çıkarmaktadır. ${ }^{76}$

Türkiye, tüketim ve din etkileşimini özellikle dinin metalaşması veya İslam'ın ticarileşmesi ${ }^{77}$ sürecini gösteren bir tüketim toplumu örneğini oluşturmaktadır. Metalaşma sürecinde İslam dininin Türkiye toplumu sinırları içinde, kapitalist ve tüketim toplumu kodlarılla bir eklemleme göstererek kendi değer ve ritüellerine yabancılaşttğııı ve bunun yer yer gösterişçi tüketim için yapıldığını görmek mümkündür.

Türkiye tüketim toplumunda, dinin metalaştırılması ve bireyin dine yabancılaşmasının en belirgin hali, tesettür giyiminde görülmektedir. Tesettürün tüketim toplumu içinde yer bulması, ona yer açılması veya tüketilmeye zorlanmasıyla gerek biçiminde gerekse anlamında orijinalinden kopmalar meydana gelmekte ve yabancllaşma sürecine girmektedir. Tesettürdeki bu sürecin en önemli örneğinin başörtüsünde meydana geldiği söylenebilir. Örtünme, dini bir gereklilikten, sembolik bir kimlik inşasına doğru evrilerek, modern dünyada İslam dinine getirilen yeni bir yorum olarak ortaya çıkmakta; geleneksel örtünmeden ayrılması, değişimi mümkün olmayan geleneksel biçimden uzaklaşması ve modanın bir aracı olması amacıyla "türban" adı ile tanımlanmaktadır. ${ }^{78}$

Nitekim Türkiye'de 1980'li yıllardan itibaren tesettür sektöründe reklamlar başlamış ve günümüze kadar çeşitli dönüşümlere uğramıştır. İlk yapılan reklamlarda tesettür, elle çizilmiş resimlerle gösterilmekte; kadın vücudunu gösteren, kaş, göz, makyaj gibi kadın mankeni andıran reklamlar olmamaktaydı. Ancak modern dünyanın hızla gelişen medya ve reklam sektörleriyle tesettür modası da buna uymaya başlamıştır. 1990'lı yıllarda yüzleri makyajlı, örtülü gerçek mankenler kullanılmaya başlanmış; 2000'li yıllarda bunlara ek olarak vücut dili öne çıarılan, jest ve mimikleriyle albeniliği arttırılmaya

75 Veblen, Aylak Sinıfin Teorisi, 67-73.

76 Demirezen, “Tüketim Toplumunun Oluşumu ve Din İle Etkileşimi”, 103.

77 Tayfun Atay, Din Hayattan Çıkar (İstanbul: İletişim Yayınları, 2004), 8.

78 Nilüfer Göle, Modern Mahrem Medeniyet ve Örtünme, 10. Baskı (İstanbul: Metis Yayınları, 2010), 17-19. 
çalışan mankenler, reklamların ana malzemesi olmuştur. ${ }^{79}$ Böylece tesettürün kendine özgü bir modası ve tüketim piyasası doğmuştur.

Tekbir Giyim, Türkiye'de tesettür kıyafetlerini stil ve renk açısından farklılaştırarak tesettürle modayı birleştiren ilk ticari kurum olma özelliği taşımaktadır. ${ }^{80}$ Firma sahibi Karaduman tarafından yapılan açıklamalar, dini değer ve ritüeller üzerinden bireylerin dine yabancılaşmasını göstermektedir:

“Bugün bir çok kuaförün salonunda bizim defile ve kataloglarda kullandığımız modeller bağlanıyor. Baş bă̆lama modellerindeki değişimde en büyük etki siyasi baskıların yanında dini otoritelerin zayıflamış olması. Mesela eskiden bir Timur Taş Hoca vardı. Bu hocamızın verdiği vaazların konusu ne olursa olsun mutlaka örtünme konusunu da işler ve tesettürün önemini her vaazında vurgulard. Bugün insanlarl dini anlamda yönlendiren kimse olmadığ ı için herkes canının istediği gibi başını bă̆glıyor diye düşünüyorum. Eskiden bol kıyafetler büyük boy başörtülerimiz rağbet görüyordu ama şimdi kimse bu tür örtülere ve kıyafetlere ilgi göstermiyor. Herkes kendi duygu ve düşüncelerine göre örtünmeye başladı. İlk başta ürettiğimiz başörtü boyutları satılsa biz yine o model üretmeye devam ederiz. Ama biz büyük boy örtüler üretsekte onlar alıp istedikleri gibi başlarını bağlayacaktır." ${ }^{81}$

Bu gibi firmaların sayısı oldukça artmış, ayrıca tesettürü konu edinen dergiler de yayımlanmaya başlanmıştır. Tesettür moda dergilerinden Âlâ Dergisi, 2011 yılında başladığ yayın hayatından bu yana tüketim toplumuna farklı bir araç ve amaçla hizmet etmektedir. Özellikle tesettürde sade ve muhafazakâr bir kimlikten uzak durarak, makyajlı başörtülü kadınların modellik yaptığı ve dini aksesuarların marka etiketleriyle tanıtıldığg bu dergi ${ }^{82}$, "Âlâ Fashion Party Tarihteki En Büyük Kızlar Partisi" sloganıyla tesettürlü kapak kızı yarışması ve girişlerin ücretli olduğu bir parti düzenlemek istemiş, fakat muhafazakâr kesimden gelen eleştiriler üzerine iptal etmiştir. ${ }^{83}$ Kapitalist kâr güdüsünde tüketim kodlarıyla bezenerek sunulan bu tür organizasyonlar, bireylere dinlerini daha iyi yaşamaları için fırsatlar sunuyorsa da, bireylerin bu fırsatlara olan dini yöneliminin yanında yabancılaştırıcı etkiyi de beraberinde getirmektedir. Bireyler, üretim araçlarına sahip olan bu tür kitlenin yabancılaştırıcı tutumunu

79 Fatma Barbarosoğlu, Şov ve Mahrem (İstanbul: Timaş Yayınları, 2006), 126-129.

80 Zorlu, “Batılı Bir Yaşam Tarzı Olarak Tüketim: Türkiye'de Tüketim Ürünlerinin ve Kültürünün Tarihsel Gelişimi", 6.

81 "Tesettürde Vücut Hatları Devrimi”, Hürriyet Gazetesi, erişim: 2 Nisan 2019, http:// www.hurriyet.com.tr/tesetturde-vucut-hatlari-devrimi-3567169

82 Okutan, Türkiye'de Popüler Kültür Din ve Kadın Marjinalizasyondan Entegrasyona, 123-124.

83 “Tepki Geldi Asena'1ı Tesettür Partisi İptal”, Hürriyet Gazetesi, erişim: 3 Nisan 2019, http://www.hurriyet.com.tr/gundem/tepki-geldi-asenali-tesettur-partisi-iptal-26581649 
görememekte; kendilerine verilen fırsatların haz ve coşkusunda, metalaştırılan dini değerleri koşulsuz kabul etmektedirler. Bu anlamda, dinin yerel kültür endüstrisinin bir çarkı olduğu ve bunun çeşitli hallerinin Türkiye'de gün be gün arttı̆̆ görülmektedir. Ancak bu durumun yüksek dini eğitimi alan kesimlerdeki etkinliği tartışmalıdır. Nitekim Şahin'in İlahiyat Fakültesi öğrencileri üzerine yaptığı bir çalışmada; araştırmaya katılan öğrencilerin \% 43.9'luk bir diliminin medya yapımlarına yansıyan lüks yaşam biçimleri ve rol modellerinden etkilendikleri; ancak buna rağmen tüketim toplumunun medya, reklam ve moda endüstrileri aracılığıyla yoğun bir şekilde empoze ettiği bu yaşam biçimlerinden ziyade din ve aile gibi geleneksel ve koruyucu, kalıcı, muhafazakar değerleri ihtiva eden sosyolojik kurumların öğrencilerden tarafından daha fazla benimsenip içselleştirildiği görülmüştür. ${ }^{84}$

Dini gereklerin tüketim pazarına girdiğinde çeşitli değişimlerin kaçınılmaz olduğu açıktır. Nitekim tesettür modası bu değişimler doğrultusunda kendi vitrininin "in" ve "out"larını oluşturmaktadır. ${ }^{85}$ Böylece tesettür modasını izlemek örtülü kadını, kendi cemaati içinde farklılaştırmaya götürmekte, ancak genel örtünme pratiği üzerinden ise birleştirmektedir. ${ }^{86}$ Başörtüsü, bir simge olarak aşkın değerlere gönderme yapması açısından seküler/modern kadını, markalı ve belirli stillerin taşıyıcısı olarak geleneksel örtülü kadından ayırmakta; fakat genel örtünme ilkelerini barındırmasıyla dini yaşam tarzı içerisinde bir aidiyet simgesi haline gelmektedir. ${ }^{87}$

İşaret veya gösteriş değeri, tüketicinin dini değer ve ritüellerin asıl manasının görmesini engellemektedir. Çünkü tüketim toplumlarında metalaşan dinin hakiki anlamı, işaret kodlarıyla sarmalanmakta ve gizlenmektedir. Doğal olarak dindar tüketiciler, dini, salt anlam ve önemiyle değil, işaret değeri üzerinden görerek tüketim yapmaktadırlar. Bu sonuç, dini değer ve ritüellerin yabancılaşmasını açık bir şekilde ortaya koymaktadır. Lakin önemli olan nokta; bireylerin bu tür tüketim faaliyetlerini, dini gerekçelerle yaptıkları ve dini sosyal yaşamlarını sürdürmek üzere tüketime yöneldikleridir.

84 M. Cem Şahin, "Popüler Kültürün İlahiyat Fakültesi Öğrencilerinin Yaşam Stilleri Üzerindeki Etkisi", Toplum Bilimleri Dergisi 1-3/1-6, (2009): 189-191.

"İslamcı basında tesettür kavgası", Milliyet Gazetesi, erişim: 2 Nisan 2019, http://www. milliyet.com.tr/islamci-basinda-tesettur-kavgasi/guncel/haberdetayarsiv/05.08.2001/2489 26/default.htm

86 Mutlu Binark - Barış Kılıçbay, Tüketim Toplumu Bağlamında Türkiye'de Örtünme Pratiği ve Moda İlişkisi (Ankara: Konrad Adenauer Vakfı, 2000), 91.

87 Zorlu, "Batılı Bir Yaşam Tarzı Olarak Tüketim: Türkiye'de Tüketim Ürünlerinin ve Kültürünün Tarihsel Gelişimi", 6 . 
Bireylerin İslam'ın emirlerine uyma veya yaşama niyetleriyle yaptıkları tüketim, dindarlık temelinde ve dindarlık adına gösteriş yapmalarına neden olmakta ve Okumuş'un "gösterişçi dindarlık" tabiriyle yeni bir dindarlık boyutuna işaret etmektedir. Bu gösteriş̧̧i dindarlar, gerçek dindarlar gibi dini erdemliliğe ulaşma özelliği taşımamakta; insanların görmeleri, onlarla sahip oldukları veya işaret ettikleri gösterişleri üzerinden ilişki kurmaktadırlar. ${ }^{88}$ Ancak dine yabancılaşma ve gösterişçi dindarlık arasındaki fark; bireyin dini tüketiminin veya eylemlerinin niyetinin gizli kalmasıyla gerçekleşmektedir.

Bireylere, yaptıkları eylemin nedenini tek tek sormanın veya bunu araştırmanın imkânsızlığı, bizi, dini değer, ritüel ve mekanlar ile dindar veya inanan bireyler arasındaki ilişkiyi objektif olarak analiz etmeye yönlendirmektedir. Bu durumda eylemlerindeki işaret veya gösteriş anlamı ve değeri üzerinden dindarları yorumlamak da onlara karşı bir haksızlığa sebep olabilir. Bu bakımdan bireylerden öte onların bulundukları toplumsal sisteme gönderme yapmak daha sağlıklı olabilir. Çünkü metalaştırılarak dindar bireylere çeşitlilikle sunulan dini değer ve ritüeller, onlara tercih edebilme şansı veriyor görünse de, aslında din kataloglaştırılarak birey tarafından tercih etme zorundalığında bırakılmaktadır. Yani hakiki dinle etkileşimlerine engel olunmakta ve onlara sömürü ve kâr amacı güdülerek sunulan din gösterilmektedir. Özne olan bireyden önce, ona metalaştırılarak, istismar edilerek ve yine dini yaşama adına kılıfıyla meşrulaştırılarak sunulan ve tüketmeye zorlanan dini değer ve ritüelleri, bu sürece eklemleyenleri ve kapitalist çarkın dişlisi haline getirenleri öncelikli göstermek gerekmektedir. Bu bakımdan hem din hem de dindar bireylere yönelik gerçekleşecek haksızlığı, objektif olarak değerlendirmek zorlaşmaktadır. Bundan dolayıdır ki dine yabancılaşma kavramının bu durumu analiz etmek için objektif bir yöne sahip olduğu söylenebilir.

Özetle; tüketim toplumundaki dini ibadet, değerler ve diğer ihtiyaçları karşılamada, lükse, israfa ve gösterişe yönelen bir değişimin gerçekleştiği görülmektedir. Tesettür tüketiminin gerçek anlamından farklı olarak işaret değeri üzerinden ve moda, defile veya çeşitli dergilerin katkılarıyla tercih edilmesi ve ayrıca hac, umre, oruç gibi ibadetlerin ve dini değerlerin VIP etiketiyle lüks ve israf içermesi yani dinin metalaştırılarak sunulmasıyla bireylerin dine yabancılaşmaları net bir biçimde gerçekleşmektedir.

88 Ejder Okumuş, “Gösteriş̧̧i Dindarlık” Dinbilimleri Akademik Araştırma Dergisi 6/2 (2006): 24-27. 


\section{SONUÇ}

Tüketim, insanlık tarihinin başlangıcından yaşadığımız ana dek var olan bir olgudur. Bu olgu, toplumsal birçok durumla ilişkilidir. Bunlardan biri de yabancılaşma kavramıdır. Birçok düşünürün ele aldığı bu kavram, Marx tarafından sanayileşme ve kapitalizm süreçlerini analiz için daha sosyolojik veriler sunmaktadır. Marxist yabancılaşma kavramı, günümüz tüketim toplumlarını incelemede ve çözümlemede imkân sağlamakta, ancak yeterli olamamaktadır. Her ne kadar bu çalışmanın temel kavramsal alt yapısını oluştursa da, bu kavramın salt manada Türkiye tüketim toplumunu çözümlemede verimsiz kaldığı görülmektedir. Bu durum, yabancılaşmaya farklı bir boyut getirilerek veya başka bir çerçevede ele alınarak, bu çalışmayla giderilmeye çalışılmıştır. Nitekim yabancılaşmanın tezahürleri, Türkiye tüketim toplumundaki dini değer, ritüel ve mekanları üzerinden analiz edilerek gösterilmeye çalışılmıştır. Burada yapılan yabancılaşma analizi, Marx'ın kavramsal tanımından yola çıkılarak dini değer, ritüel ve mekânlardaki kopma, uzaklaşma ve başkalaşmayı gözler önüne sererek yapılmaktadır. Aksine bu çalışma, mutlak bir Marksist yabancılaşma analizi olmayıp, yabancılaşmanın benzer nitelikleriyle din ile etkileşimini gösterme üzerinedir.

Türkiye toplumunda tüketim toplumu ve dine yabancılaşma ilişkisi belli başlı örneklerle yukarıda ifade edilmeye çalışılmıştır. Dinin meta olarak görülmeye başlanmasıyla dinin hakiki anlamından kopuşa, uzaklaşmaya ve başkalaşmaya götürdüğü ve Türkiye toplumunda tüketim kodlarının etkisiyle birçok alanda dine yabancılaşmayı ortaya çıkardığı belirtilmiştir. Dine yabancılaşma, bu çalışmada dini değer, ritüel ve mekânların orijinal anlamlarından uzaklaşması, bireye başkalaşması ve tüketim toplumunun bir metası olarak merkez anlamında değil işaret değeri üzerinden satın alınmasıyla nesneleşmesinin tezahürlerini kapsamaktadır. Bu sürece etki eden tezahür ortamlarından biri modadır. Nitekim modayla beraber dini gerekliliğin bir tezahürü olarak tesettürde seri üretim başlamış ve bu üretim sonucunda sunulan ürünlerin satın alınması için reklamlar ve giyim sektörünün olmazsa olmazlarından olan defileler sektörde yer edinmiştir. Bu defileler, dini anlama sahip bir eşyanın pazarlama kodlarıyla metalaşmasına ve merkezinden kopmasına yol açarak, dinin işaret değeri üzerinden oluşturulan anlamiyla tüketilmesine ve bunun sonucunda dine mensup kişilerce yabancılaşmasının bir tanıtımını podyumlara taşımaktadır. Böylece podyuma çıkan tesettür ve başörtülü kimlik bir şov aracına dönüşmektedir. ${ }^{89}$ 
Şov ve gösteriş malzemesi olan ve israfa ve gösterişe yönelten tesettür reklamları ve medyası, Müslüman kadınların bazılarına göre dinlerini daha iyi yaşamak için yaptıkları alışverişi, metalaşma kıskacına sokmaktadır. Özetle; bireylerin mensup oldukları dinin inanç ve gereklerine göre yaşama isteklerini karşılamak üzere kapitalist tüketim kodlarıyla süslenerek sunulan ve Marxist manada, bireylerin kendi elleriyle veya üretim araçlarına sahip burjuva sınıfıyla moda, reklam vb. araçlarla önlerine getirilen din, bireylerce satın almak zorunda bırakılmalarıyla yabancılaşmalarına götürülmekte ve dine yabancılaşmanın bir başka boyutunu göstermektedir. Türkiye toplumu da bir tüketim toplumu olarak, dini değerlerin kapitalist bir meta gibi kullanıldığı ve yer yer dini metaların fetiş hale getirildiği bir toplum örneği olarak buna analiz imkânı vermektedir.

Tüketim toplumlarının her şeyiyle kâr ve tüketime yönlendirme üzerine kurulmuş çabası, Türkiye'de dinin meta olarak pazarlanmasına; bireylerin Müslüman kimlikleri dâhil olmak üzere dini ibadetlere ve değerlere yabancılaşmasına sebep olmaktadır. Özellikle kadınların dini ritüellerin anlamları konusunda, tüm eleştirilere ve tartışmalara açık olarak, kopmalar yaşaması ve dine yabancılaşmaları görülmektedir. Bundan dolayı tüketim, bireyin, kendisi ve inançları üzerine düşünmesine engel olmakta; onu meta tutkusuna köle bir bireye götürmekte ve onun aslolan aşkın ile ilişkisini kesmektedir. Tüm bunların sonunda, dinin metalaşma sürecinin etkisi altındaki bireyler, içinde bulundukları tüketim toplumunda, dinin gereklerini icra ederken veya etmeye çaba gösterirken, dini değer, ritüel ve mekanlarına peyder pey yabancılaşmaktadır. Bu durum, Marx'ın sanayileşme sonrası kapitalist sistemdeki bireylerde gördüğü dört yabancılaşma boyutuyla rahatça ilişkilendirilmekte ve yeni bir boyut olarak dine yabancılaşmaya götürmektedir.

Bu çalışmanın, bir giriş, bu konuya dair bir açıklama veya çözümleme getirilmeye çaba gösterilen bir deneme olduğu göz önünde tutularak, çeşitli araştırmaların yapılmasına veya yapılanların farklı bir perspektiften de okunabilmesine fayda sağlayacağını ve ışık tutacağını ummaktayız. 


\section{KAYNAKÇA}

Atay, Tayfun. Din Hayattan Çıkar. İstanbul: İletişim Yayınları, 2004.

Aydın, Mustafa. Güncel Kültürde Temel Kavramlar. İstanbul: Açılımkitap Yayınevi, 2011.

Barbarosoğlu, Fatma. Şov ve Mahrem. İstanbul: Timaş Yayınları, 2006.

Baudrillard, Jean. Tüketim Toplumu Söylenceleri Yapıları. Trc. Hazal Deliceçaylı - Ferda Keskin. 5. Baskı. İstanbul: Ayrıntı Yayınları, 2012.

Bauman, Zygmunt. Özgürlük. Trc. Kübra Eren. 2. Baskı. İstanbul: Ayrıntı Yayınları, 2016.

Berger, Peter Ludwig. Kutsal Şemsiye Dinin Sosyolojik Teorisinin Ana Unsurları. Trc. Ali Coşkun. 4. Baskı. İstanbul: Rağbet Yayınları, 2011.

Binark, Mutlu - Kılıçbay, Barış. Tüketim Toplumu Bă̆lamında Türkiye'de Örtünme Pratiği ve Moda İlişkisi. Ankara: Konrad Adenauer Vakfı, 2000.

Bocock, Robert. Tüketim. Trc. İrem Kutluk. 3. Baskı. Ankara: Dost Kitapevi, 2009.

Bulaç, Ali. İnsanın Özgürlük Arayışı. İstanbul: İnkılap Kitapevi, 2015.

Coşgun, Melek. "Popüler Kültür ve Tüketim Toplumu". Batman Üniversitesi Yaşam Bilimleri Dergisi 1/1 (2012): 837-850.

Çakmak, Muhammet. "Yabancılaşma Kavramı Üzerine Bazı Değerlendirmeler ve Kur'an'ın Yabancılaşma Kavramına Bakışı”. Fırat Üniversitesi İlahiyat Fakültesi Dergisi, 1(1996): 301-312.

Çarkoğlu, Ali - Kalaycıŏlu, Ersin, “Türkiye'de Dindarlık: Uluslararası Bir Karşılaştırma". İstanbul Politikalar Merkezi (2009): 1-43.

Çubukçuoğlu, M. Emre - Haşılıoğlu, S. Burak, "Dindarlık Olgusunun Satınalma Davranışı Faktörleri Üzerine Etkisi". Tüketici ve Tüketim Araştırmaları Dergisi 4/1 (2012): 1-18.

Debord, Guy. Gösteri Toplumu ve Yorumları. Trc. Ayşen Ekmekçi - Okşan Taşkent. 4. Baskı. İstanbul: Ayrıntı Yayınları, 2012.

Demirezen, İsmail. "Tüketim Toplumunun Oluşumu ve Din ile Etkileşimi". Dinbilimleri Akademik Araştırma Dergisi 10/3 (2010): 97-109.

Demirezen, İsmail. Tüketim ve Din. İstanbul: Ensar Neşriyat, 2015.

Featherstone, Mike. Postmodernizm ve Tüketim Kültürü. Trc. Mehmet Küçük. 3. Baskı. İstanbul: Ayrıntı Yayınları, 2013.

Fromm, Erich. Marx'ın İnsan Anlayışı. Trc. Kaan H. Ökten. İstanbul: Antan Yayınevi, 2004. 
Göle, Nilüfer. Modern Mahrem Medeniyet ve Örtünme. 10. Baskı. İstanbul: Metis Yayınları, 2010.

Hürriyet Gazetesi. "Tepki Geldi Asena'lı Tesettür Partisi İptal”. Erişim: 3 Nisan 2019. http://www.hurriyet.com.tr/gundem/tepki-geldi-asenalitesettur-partisi-iptal-26581649

Hürriyet Gazetesi. "Tesettürde Vücut Hatları Devrimi". Erişim: 2 Nisan 2019. http://www.hurriyet.com.tr/tesetturde-vucut-hatlari-devrimi3567169

Hürriyet Gazetesi. "VIP Hac butik umre”. Erişim: 2 Nisan 2019. http:// www.hurriyet.com.tr/ekonomi/vip-hac-butik-umre-40362973

Iannaccone, Laurence Robert. "Voodoo Economics? Reviewing The Rational Choice Approach to Religion". Journal for the Scientific Study of Religion 34/1 (1995): 76-88.

Köksal, Emrah. "Kurumsal Yabancılaşma". Polis Bilimleri Dergisi 12/2 (2010): 107-123.

Marshall, Gordon. "Suç". Sosyoloji Sözlüğ̈̈. Trc. Osman Akınbay - Derya Kömürcü. Ankara: Bilim ve Sanat Yayınları, 2014.

Marx, Karl. Kapital, Kapitalist Üretimin Eleştirel Bir Tahlili. Trc. Alaattin Bilgi. 2. Baskı. 1. Cilt. Ankara: Sol Yayınları, 1978.

Marx, Karl. "1844 El Yazmaları". Yabancılaşma. Trc. Barışta Erdost. 4. Baskı. Ankara: Sol Yayınları, 2010.

Milliyet Gazetesi. "İslamcı basında tesettür kavgası". Erişim: 2 Nisan 2019. http://www.milliyet.com.tr/islamci-basinda-tesettur-kavgasi/guncel/ haberdetayarsiv/05.08.2001/248926/default.htm

Ofluoğlu, Gökhan - Büyükyılmaz, Ozan. “Yabancılaşmanın Teorik Gelişimi ve Tarihsel Süreç İçinde Farklı Alanlarda Görünümleri". Kamu-İş Dergisi 10/1( 2008): 113-144.

Okumuş, Ejder. "Gösterişçi Dindarlık". Dinbilimleri Akademik Araştırma Dergisi 6/2 (2006): 17-35.

Okumuş, Ejder. Dinin Meşrulaştırma Gücü. İstanbul: Özgü Yayınları, 2005.

Okutan, Birsen Banu. Türkiye'de Popüler Kültür Din ve Kadın Marjinalizasyondan Entegrasyona. İstanbul: Düşün Yayıncilık, 2013.

Orçan, Mustafa. Osmanlı'dan Günümüze Türk Tüketim Kültürüu. 2. Bask1. Ankara: Harf Eğitim Yayıncılığı, 2008.

Özbudun Sibel - Demirer, Temel - Markus, George. Yabancılaşma Ve.... Ankara: Ütopya Yayınevi, 2007. 
Pappenheim, Fritz. Modern İnsanın Yabancılaşması Marx'a ve Tönnies'ye Dayalı Bir Yorum. Trc. Salih Ak. Ankara: Phoenix Yayınevi, 2002.

Swain, Dan. Yabancilaşma Marx'ın Teorisine Bir Giriş. Trc. Hande T. Urbarlı. İstanbul: Durak İstanbul Yayıncılık, 2013.

Şahin, M. Cem. "Popüler Kültürün İlahiyat Fakültesi Öğrencilerinin Yaşam Stilleri Üzerindeki Etkisi”. Toplum Bilimleri Dergisi 1-3/1-6, (2009): 167-200.

Şahin, M. Cem. "Postmodern Dönemde Tüketim Olgusunun SosyoKültürel Analizi ve Yabancılaşma". Dini Araştırmalar 11/31 (2008): 173-194.

The Guardian. "Be Muslim for a month in Istanbul: pray five times a day and fast". Erişim: 2 Nisan 2019. https://www.theguardian.com/travel/2011/ apr/21/muslim-for-month-istanbul-turkey

Tuğcu, Tuncar. Yabancılaşma Problemi Hıristiyanlı̆̆ın ve Marksizmin Kökleri. Ankara: Alesta Yayınevi, 2002.

Türk Dil Kurumu. “Tüketim". Erişim: 1 Nisan 2019. http://www. tdk.gov.tr/index.php?option=com_gts\&arama=gts\&guid=TDK. GTS.5cb1af99a82563.73286365

Veblen, Thorstein. Aylak Sinıfin Teorisi. Trc. Zeynep Gültekin - Cumhur Atay. İstanbul: Babil Yayınları, 2005.

Wolff, Jonathan. Why Read Marx Today. New York: Oxford University Press, 2002. 